\title{
Study of the Particulate Purification Efficiency of Diesel Oxidation Cata- lyst and Catalyzed Diesel Particulate Filter
}

\author{
TAN Pi-qiang, ZHANG Xiao-feng, HU Zhi-yuan, LOU Di-ming \\ School of Automobile, Tongji University, Shanghai 201804
}

KEYWORD: Diesel engine, Particulate, Diesel oxidation catalyst, Catalyzed diesel particulate filter ABSTRACT: The combination of diesel oxidation catalyst (DOC) and catalyzed diesel particulate filter (CDPF) is one of the most effective ways to control particulate emission. Particulate number (PN) and size distribution characteristics are studied when a heavy duty diesel equipped with or without DOC $+\mathrm{CDPF}$ in this paper. Results show that no matter the DOC $+\mathrm{CDPF}$ after-treatments are equipped or not, the power outputs and torques under the same condition are nearly the same, and the fuel consumption will be increased of about $2 \%$ when equipped with DOC+CDPF. When the diesel engine works without $\mathrm{DOC}+\mathrm{CDPF}$, the size distribution of exhaust particulate number shows double-peak logarithmic distribution under most conditions, and the peak diameters of particulate number are about $50 \mathrm{~nm}$ and $200 \mathrm{~nm}$. When equipped with DOC $+\mathrm{CDPF}$, the size distribution of particulate number shows multi-peak logarithmic distribution, and the peak diameters of particulate number are about $10 \mathrm{~nm}, 20 \mathrm{~nm}$ and $60 \mathrm{~nm}$. The total particulate number decreases significantly, the decreasing range is more than 2 orders of magnitude when equipped with DOC $+\mathrm{CDPF}$.

\section{INTRODUCTION}

Diesel particulate emission is one of the most important sources of atmospheric pollution, particulate may contain polycyclic aromatic hydrocarbons which may be carcinogenic, and it's much possible to be inhaled when the size of particulate is small enough. Using exhaust after-treatment technology to control particulate emission is the development trend of diesel engine technology, and the combination of Diesel Oxidation Catalyst (DOC) and Catalyzed Diesel Particulate Filter (CDPF) is a common technical method ${ }^{[1]}$.

DOC is ceramic honeycomb carrier or metal honeycomb carrier which is coated with precious metal catalyst ( $\mathrm{Pt}, \mathrm{Pd}$, etc.), DOC can increase the rate of chemical reactions by lowering the activation energy, so Hydrocarbon (HC), Carbon monoxide (CO) and Soluble Organic Fractions (SOF) will be transformed to water and carbon dioxide under low temperature ${ }^{[2 \sim 4]}$. CDPF is recognized as one of the most effective method of purifying diesel engine particulate emission ${ }^{[5 \sim 7]}$. Due to the precious metal catalyst ( $\mathrm{Pt}, \mathrm{Pd}$, etc.) that is coated on the surface of DPF carrier, the light-off temperature can be reduced to $250 \sim 500^{\circ} \mathrm{C}$, which is normal exhaust temperature range when a diesel engine works, so CDPF can realize the regeneration ${ }^{[8 \sim 10]}$. To combine DOC and CDPF after-treatment can not only ensure a continuous and reliable particle trap to reduce PM emission, but also effectively reduce $\mathrm{HC}$ and $\mathrm{CO}$, etc. ${ }^{[11 \sim 13]}$. What is more, to meet the National $\mathrm{V}$ emission law in the future, it is viable to use DOC+CDPF, but how the diesel PM emission characteristic will perform after $\mathrm{DOC}+\mathrm{CDPF}$, it is necessary to carry out related research ${ }^{[14 \sim 16]}$.

\section{EXPERIMENT ENGINE FUEL AND EQUIPMENT}

\section{Test engine}

This paper takes experiment on a heavy diesel engine with high pressure common rail fuel injection system, the technical parameters are presented in Table 1. 
Table 1. Main Specifications of the Engine

\begin{tabular}{cc}
\hline Items & Parameters \\
\hline Displacement $(\mathrm{L})$ & 8.82 \\
Cylinder & L-6 Six Cylinder In- \\
Line, 4 valves \\
Cylinder Diameter / & $114 / 144$ \\
Stoke $(\mathrm{mm})$ & $18: 1$ \\
Compression Ratio & $184 / 2200 \mathrm{r} / \mathrm{min}$ \\
Rated Power $(\mathrm{kW})$ & $1000 / 1400 \mathrm{r} / \mathrm{min}$ \\
Maximum Torque $(\mathrm{N} \cdot \mathrm{m})$ & \\
\hline
\end{tabular}

\section{Test fuel}

This paper uses Shanghai V diesel fuel (similar to Euro V), the physicochemical properties are presented in Table2.

Table 2. Fuel Physicochemical Properties

\begin{tabular}{cc}
\hline Items & Diesel \\
\hline Density $\left(\mathrm{kg} / \mathrm{m}^{3}\right)$ & 821.9 \\
Kinematic Viscosity $\left(\mathrm{mm}^{2} / \mathrm{s}^{-1}\right)$ & 4.54 \\
Flash Point $\left({ }^{\circ} \mathrm{C}\right)$ & 92.0 \\
Cetane Number & 52.3 \\
Low Heating Value $(\mathrm{MJ} / \mathrm{kg})$ & 43.96 \\
Sulphur Content $(\mathrm{mg} / \mathrm{kg})$ & $<1$ \\
\hline
\end{tabular}

\section{Exhaust gas After-treatment}

This paper uses DOC+CDPF after-treatment, the technical parameters are presented in Table3.

\begin{tabular}{|c|c|c|}
\hline Items & DOC & CDPF \\
\hline Carrier Length(mm) & 295 & 304.8 \\
\hline $\begin{array}{l}\text { Carrier Diame- } \\
\text { ter(mm) }\end{array}$ & 90 & 285.8 \\
\hline Cell Density(cpsi) & 300 & 200 \\
\hline Porosity $(\%)$ & - & 55 \\
\hline $\begin{array}{l}\text { Average Pore } \\
\text { Size }(\mu \mathrm{m})\end{array}$ & - & $8 \sim 13$ \\
\hline Wall Thickness(mm) & - & 0.35 \\
\hline Carrier Material & $\begin{array}{l}\text { cordie- } \\
\text { rite }\end{array}$ & $\begin{array}{l}\text { cordie- } \\
\text { rite }\end{array}$ \\
\hline $\begin{array}{l}\text { Coating Composi- } \\
\text { tion }\end{array}$ & $\mathrm{Al}_{2} \mathrm{O}_{3}$ & $\mathrm{Al}_{2} \mathrm{O}_{3}$ \\
\hline $\begin{array}{c}\text { Catalyst Composi- } \\
\text { tion } \\
\end{array}$ & $\mathrm{Pt} / \mathrm{Pd}$ & $\mathrm{Pt} / \mathrm{Pd}$ \\
\hline
\end{tabular}

\section{Experimental Instrument}

The measurement and control system of engine bench consists of AVL-PUMA automatic test console, AVL electric dynamometer and auxiliary equipment. This system couples the dynamometer with the diesel engine, so that testers can set different rotational speed and torque to force the diesel to operate under the condition of requirement, and record the parameters constantly.

This paper uses type EEPS-3090 diesel engine exhaust particulate diameter spectrometer, which is made by TSI Company in the United States, to take particulate test. The range of particulate diameter of this instrument is $5.6 \sim 550 \mathrm{~nm}$, and its maximum test frequency is $10 \mathrm{~Hz}$, it is to say that tester may obtain a complete particulate size distribution graph within $0.1 \mathrm{~s}$, and meanwhile obtain a particulate number concentration result of 32 different diameters. EEPS-3090 is equipped with TSI MD19 rotate diluter, and its dilution ratio is 250 times. 


\section{Test procedure}

This paper takes experiment on a heavy diesel engine fuelled with Shanghai V diesel fuel, and research on particulate number (PN) and size distribution characteristics with and without $\mathrm{DOC}+\mathrm{CDPF}$.

Test condition including the working condition of full-load characteristic and part-load characteristic conditions: (1)Full-load characteristic in this experiment is the engine working at 800, 1000, 1200, 1400, 1600, 1800, 2000 and 2200r/min, totally 8 points. (2)Part-load characteristic condition consists of the maximum torque speed, $1400 \mathrm{r} / \mathrm{min}$; and the calibration speed, $2200 \mathrm{r} / \mathrm{min}$, and the load points are $10 \%, 25 \%, 50 \%, 75 \%$ and $100 \%$, totally 10 points. This paper is aimed at testing the power performance, fuel economy and particulate number $(\mathrm{PN})$ and size distribution characteristics with and without DOC+CDPF under the test conditions.

\section{RESULTS AND DISCUSSION}

\section{Power}

Figure 1 and Figure 2 show the power output and torque of the diesel engine when the engine works under full-load condition. No matter the DOC $+\mathrm{CDPF}$ after-treatments are equipped or not, the power outputs and torques under the same condition are nearly the same, that means DOC+CDPF have almost no effect on power performance of the diesel engine.

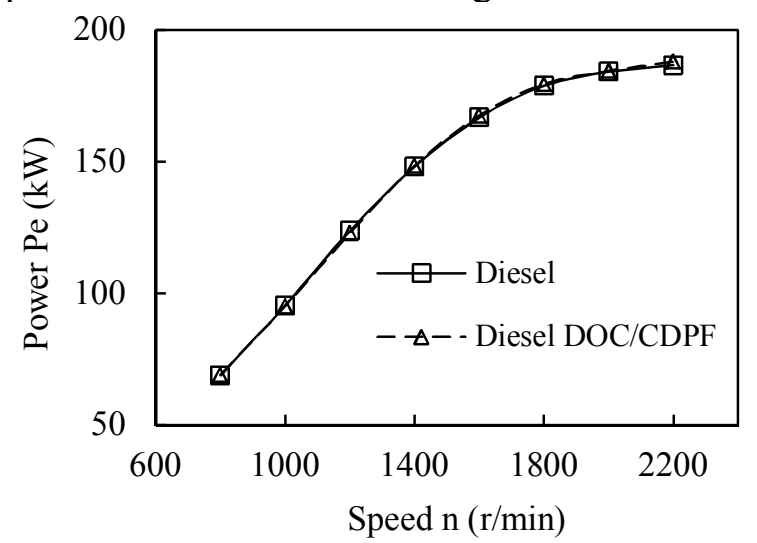

Figure 1. Power at full-load

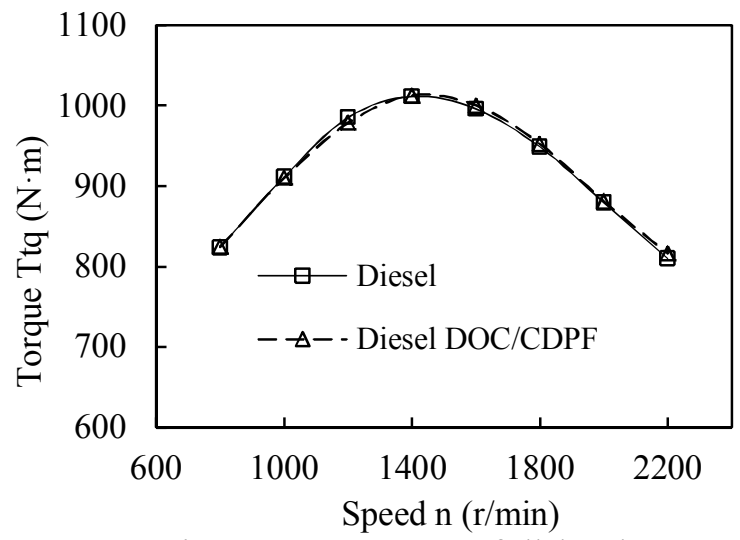

Figure 2. Torque at full-load

\section{Fuel Consumption}

Figure 3 shows the fuel consumption of the diesel engine when the engine works under full-load condition. Figure 4 and Figure 5 show the fuel consumption of the diesel engine when the engine works under part-load condition. BMEP is short for Brake Mean Effective Pressure. The fuel consumption will be increased of about $2 \%$ when equipped with DOC + CDPF, that is because CDPF can increase exhaust back pressure, which will increase the residual exhaust gas in combustion chamber and the flaming condition in the cylinder turns terrible, then the combustion thermal efficiency becomes lower. 


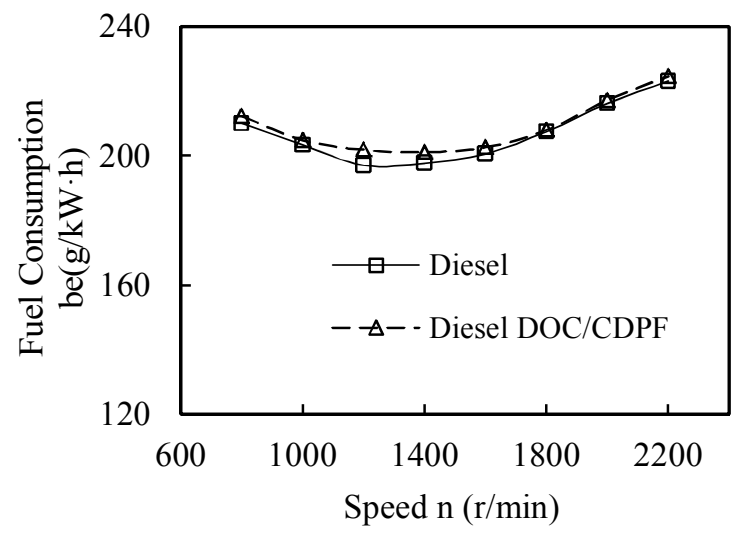

Figure 3. Fuel Consumption at full-load

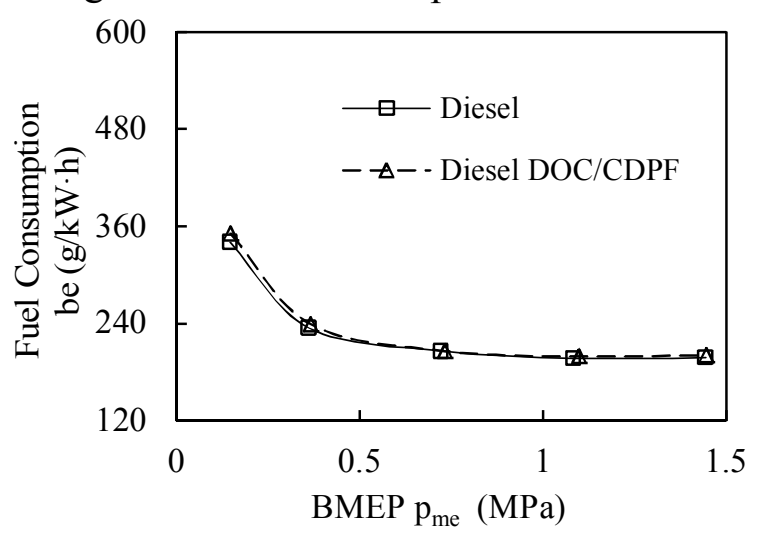

Figure 4. Fuel Consumption, 1400r/min

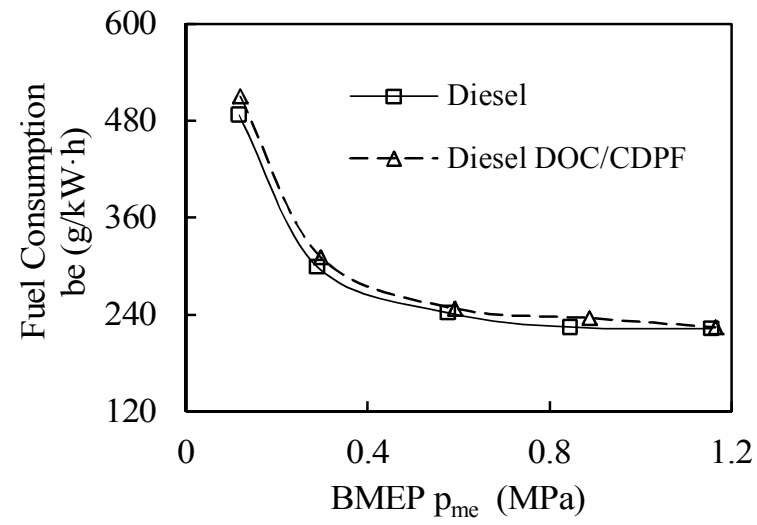

Figure 5. Fuel Consumption, 2200r/min

\section{Particulate number and size distribution characteristics}

Figure 6 and Figure 7 show the particulate number and size distribution characteristics when the engine works at $1400 \mathrm{r} / \mathrm{min}$ and $2200 \mathrm{r} / \mathrm{min}$, the load points are $10 \%, 25 \%, 50 \%, 75 \%$ and $100 \%$.

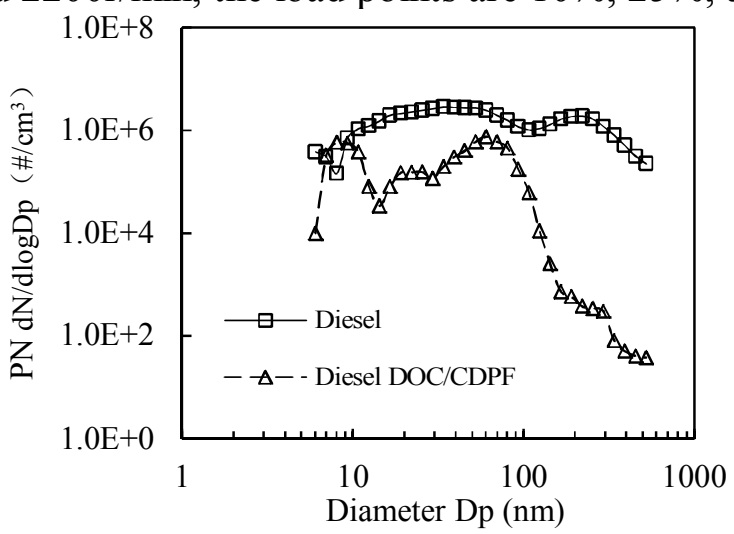

(a) $10 \%$ load 


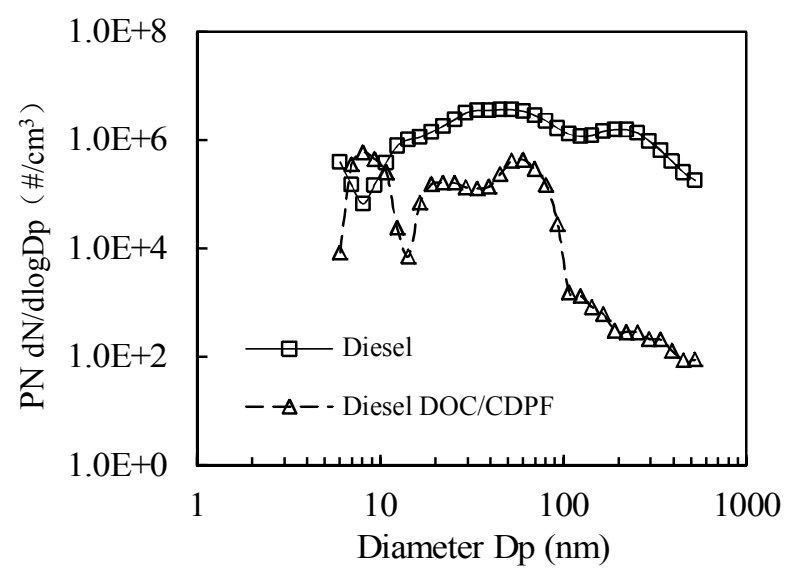

(b) $25 \%$ load

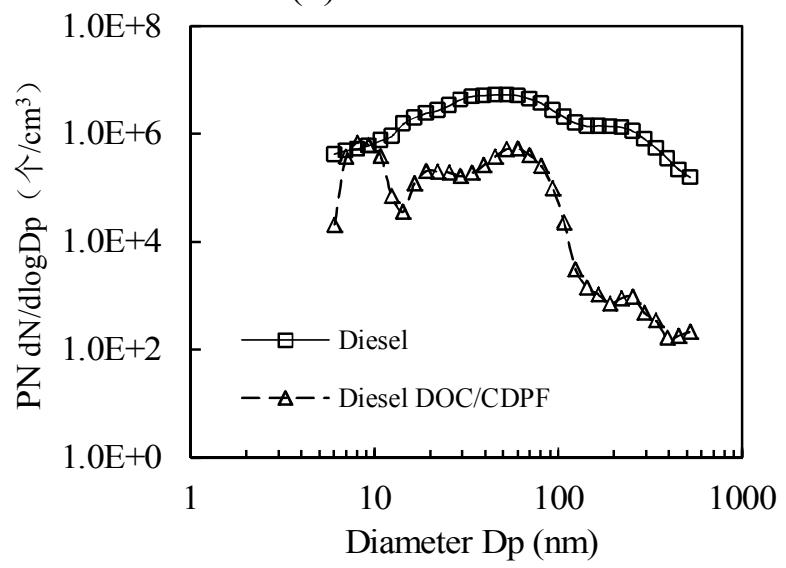

(c) $50 \%$ load

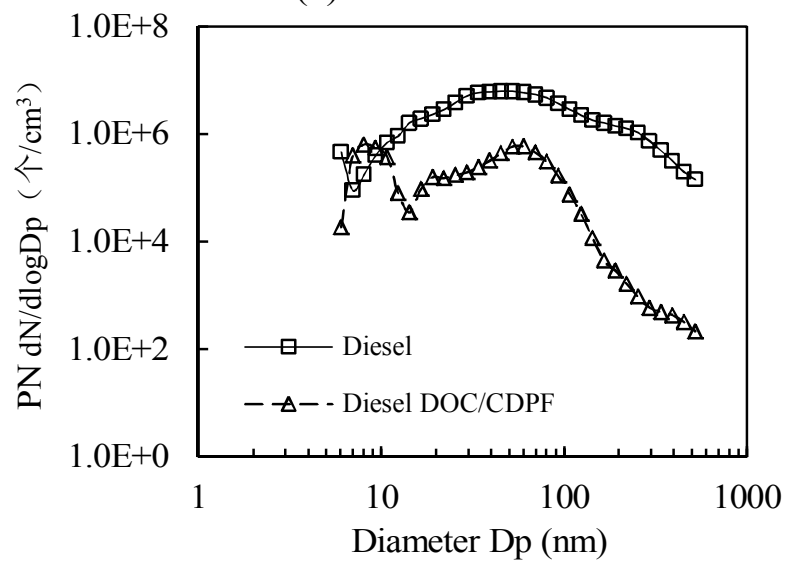

(d) $75 \%$ load

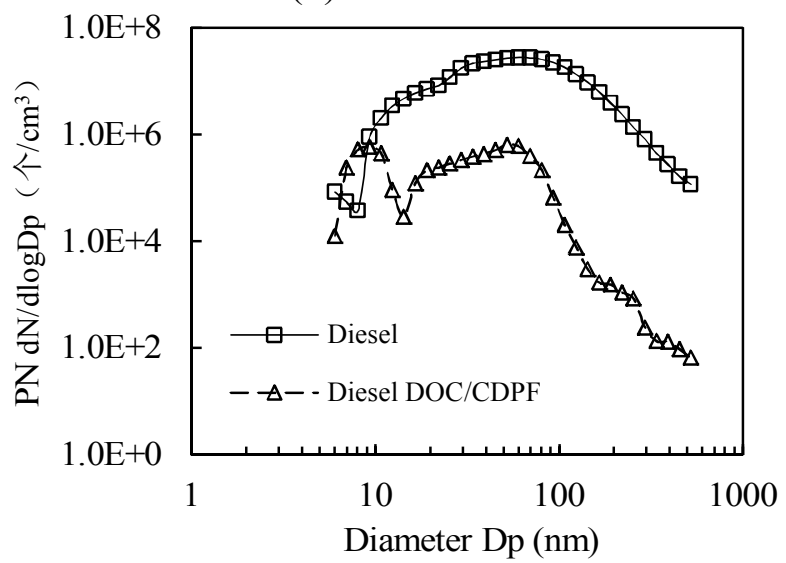

(e) $100 \%$ load

Figure 6. Particulate number and size distribution characteristics at different loads, $1400 \mathrm{r} / \mathrm{min}$ 


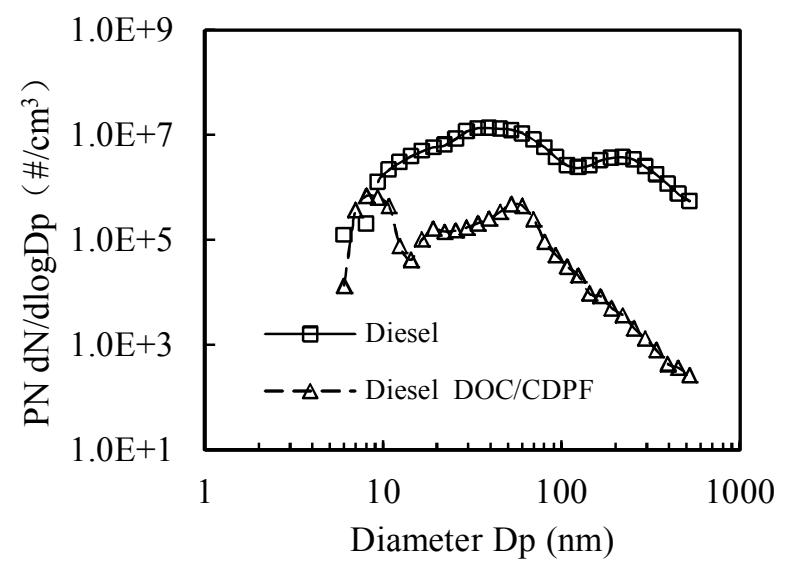

(a) $10 \%$ load

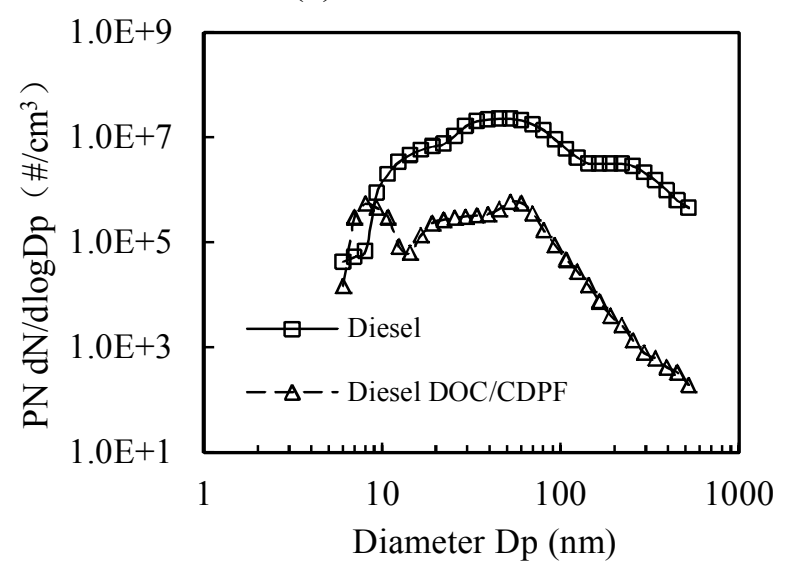

(b) $25 \%$ load

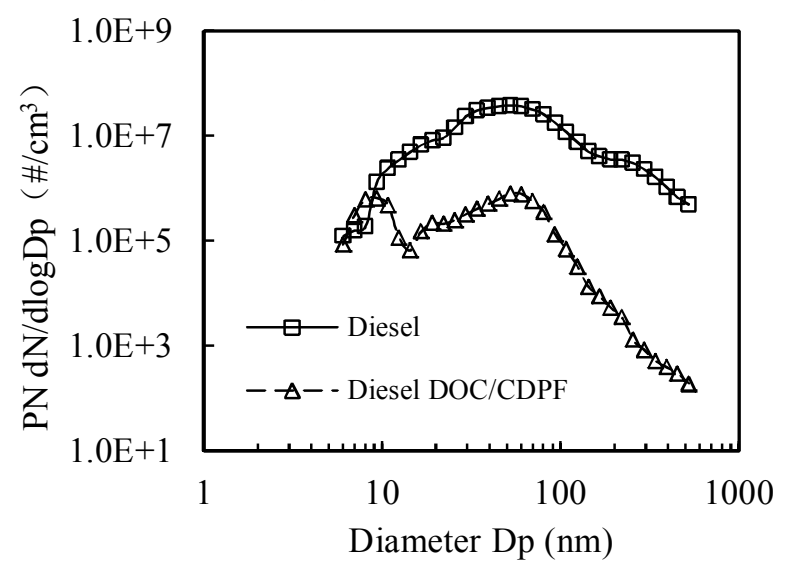

(c) $50 \%$ load

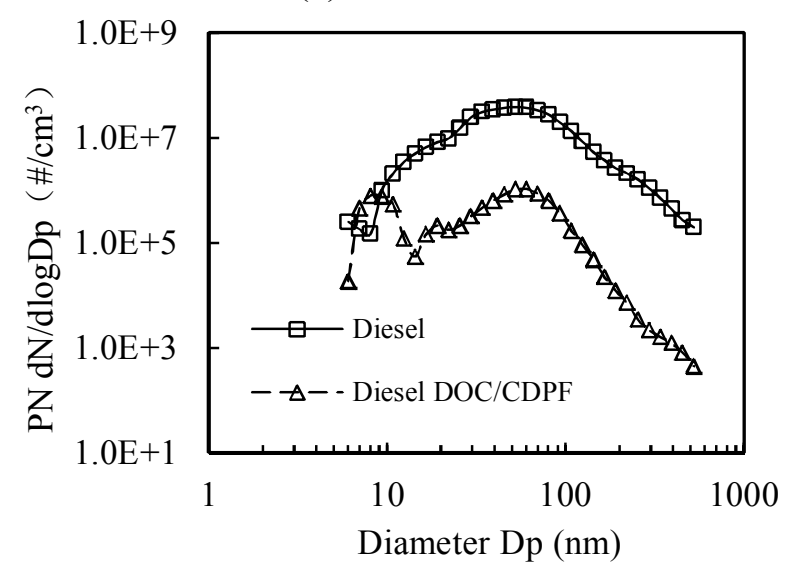

(d) $75 \%$ load 


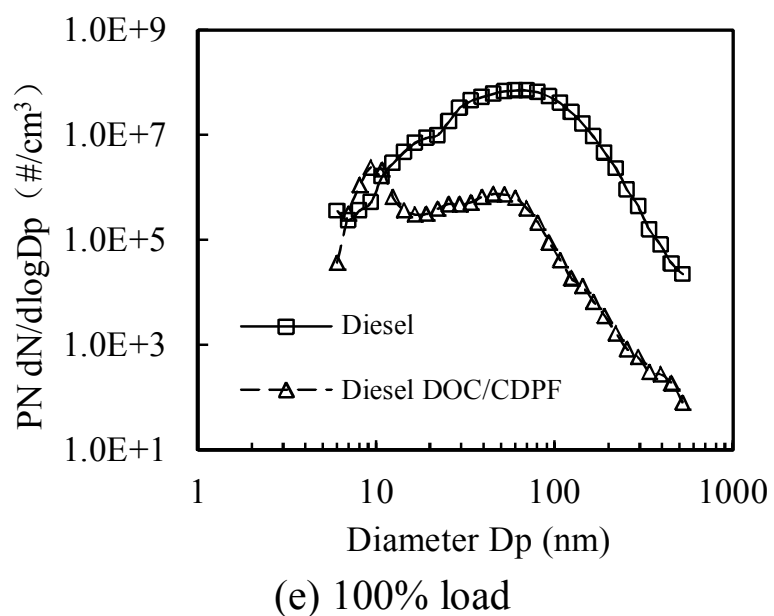

Figure 7. Particulate number and size distribution characteristics at different loads, 2200r/min

It can be seen from Figure 6(a),(b),(c),(d) that when the diesel engine works without DOC+CDPF and at a speed of $1400 \mathrm{r} / \mathrm{min}$, and the loads are $10 \%, 25 \%, 50 \%$ and $75 \%$, the size distribution of exhaust particulate number shows double-peak logarithmic distribution, it is to say that there are two peaks in each figure, and the peak diameter of particulate number are about $50 \mathrm{~nm}$ and $200 \mathrm{~nm}$. And it can be seen from Figure 6(e) that when the diesel engine works without DOC+CDPF and at a speed of $1400 \mathrm{r} / \mathrm{min}$, and the loads is $100 \%$, the size distribution of exhaust particulate number shows single-peak logarithmic distribution, and the peak diameter of particulate number is about $50 \mathrm{~nm}$.

It can be seen from Figure 7(a),(b) that when the diesel engine works without DOC+CDPF and at a speed of $2200 \mathrm{r} / \mathrm{min}$, and the loads are $10 \%$ and $25 \%$, the size distribution of exhaust particulate number shows double-peak logarithmic distribution, it is to say that there are two peaks in each figure, and the peak diameter of particulate number are about $50 \mathrm{~nm}$ and $200 \mathrm{~nm}$. And it can be seen from Figure 6(c),(d),(e) that when the diesel engine works without DOC+CDPF and at a speed of $2200 \mathrm{r} / \mathrm{min}$, and the loads is $50 \%, 75 \%$ and $100 \%$, the size distribution of exhaust particulate number shows single-peak logarithmic distribution, and the peak diameter of particulate number is about $50 \mathrm{~nm}$.

It can be seen from Figure 6 and Figure 7 that when equipped with DOC + CDPF, no matter the diesel work at which condition, the size distribution of particulate number shows multi-peak logarithmic distribution, and the peak diameter of particulate number are about $10 \mathrm{~nm}, 20 \mathrm{~nm}$ and $60 \mathrm{~nm}$. Compared to the engine without exhaust gas after-treatment, DOC $+\mathrm{CDPF}$ can evidently reduce particulate number when the engine using diesel fuel. The particulate number purification efficiency of $\mathrm{DOC}+\mathrm{CDPF}$ is a bit low when the particulate diameter is about $7 \sim 9 \mathrm{~nm}$, even in some conditions, the particulate number become larger. That is because that many particulates are sulfate at this area, and sulfate can't be by DOC+CDPF, but at the same time, large particulate is decomposed to small particulate, so the particulate number become larger when he particulate diameter is about $7 \sim 9 \mathrm{~nm}$. When the particulate diameter is about $10 \sim 60 \mathrm{~nm}$, the decreasing range is more than 2 orders of magnitude. And it even reaches 3 orders of magnitude when the range of particulate diameter is larger than $60 \mathrm{~nm}$.

\section{Total particulate number}

Figure 8 shows the total of particulate number when the diesel engine works at $1400 \mathrm{r} / \mathrm{min}$ and $2200 \mathrm{r} / \mathrm{min}$. Figure 9 shows the purification efficiency of DOC+CDPF. 


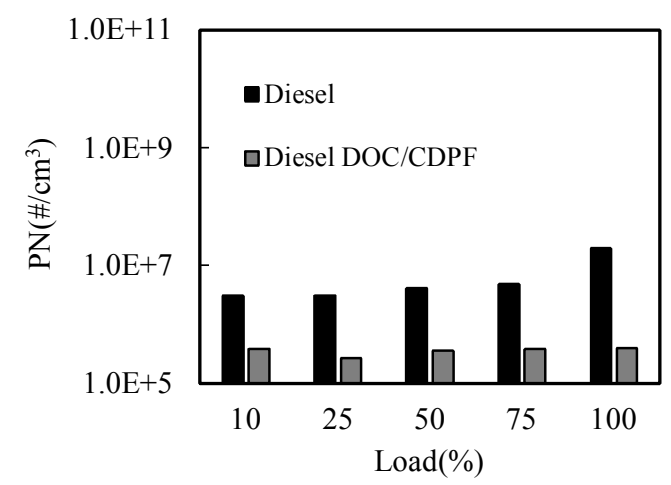

(a) $1400 \mathrm{r} / \mathrm{min}$

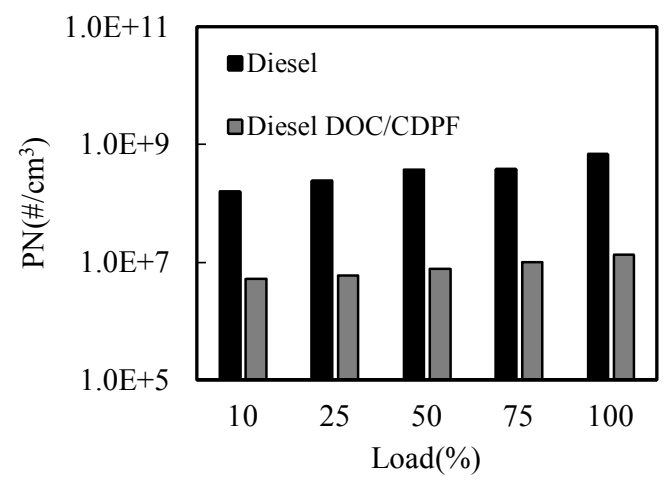

(b) $2200 \mathrm{r} / \mathrm{min}$

Figure 8. Total particulate number

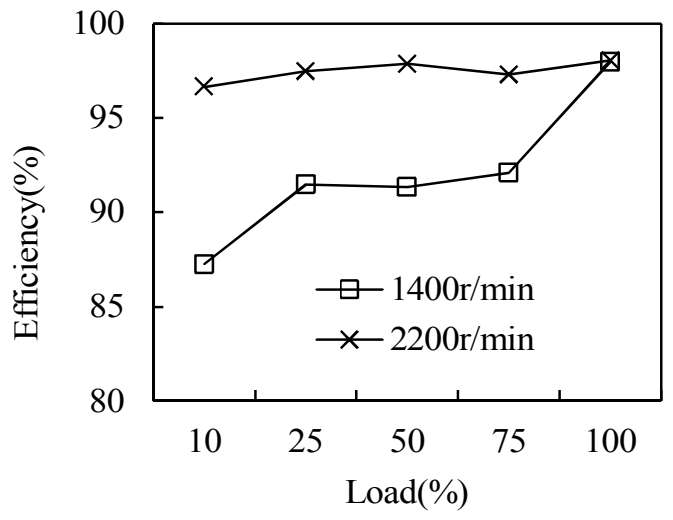

Figure 9. The purification efficiency of DOC $+\mathrm{CDPF}$

It can be seen from Figure 8 that when the engine works without DOC $+\mathrm{CDPF}$, the particulate number concentrations increase with the increase of load.

It can be seen from Figure 8 and Figure 9 that when equipped with DOC $+C D P F$, the total of particulate number decreases significantly, the decreasing range is more than 2 orders of magnitude. When the diesel engine works at $1400 \mathrm{r} / \mathrm{min}$, the average purification efficiency of DOC+CDPF is about $92.0 \%$; and $97.5 \%$ at $2200 \mathrm{r} / \mathrm{min}$.

\section{CONCLUSIONS}

(1) No matter the DOC+CDPF after-treatments are equipped or not, the power outputs and torques under the same condition are nearly the same, that means DOC+CDPF have almost no effect on power performance of the diesel engine.

(2) The fuel consumption will be increased of about $2 \%$ when equipped with DOC+CDPF, that is because CDPF can increase exhaust back pressure. 
(3) When the diesel engine works without DOC $+\mathrm{CDPF}$, the size distribution of exhaust particulate number shows double-peak logarithmic distribution or single-peak logarithmic distribution, and the peak diameter of particulate number are about $50 \mathrm{~nm}$ and $200 \mathrm{~nm}$.

(4) When equipped with DOC+CDPF, no matter the diesel work at which condition, the size distribution of particulate number shows multi-peak logarithmic distribution, and the peak diameter of particulate number are about $10 \mathrm{~nm}, 20 \mathrm{~nm}$ and $60 \mathrm{~nm}$.

(5) When the engine works without $\mathrm{DOC}+\mathrm{CDPF}$, the particulate number concentrations increase with the increase of load. And when equipped with DOC $+C D P F$, the total particulate number decreases significantly, the decreasing range is more than 2 orders of magnitude.

\section{REFERENCES}

[1] Ong H.C., et al. 2014. Engine performance and emissions using Jatropha curcas, Ceiba pentandra and Calophyllum inophyllum biodiesel in a CI diesel engine[J]. Energy 69: 427-445.

[2] Zhu L., et al. 2013. Effects of ethanol-biodiesel blends and diesel oxidation catalyst (DOC) on particulate and unregulated emissions[J]. Fuel 113: 690-696.

[3] Sharma H. \& Mhadeshwar A. 2012. A detailed microkinetic model for diesel engine emissions oxidation on platinum based diesel oxidation catalysts (DOC) [J]. Applied Catalysis B: Environmental 127: 190-204.

[4] Johns T.R. et al. 2015. Relating adatom emission to improved durability of Pt-Pd diesel oxidation catalysts[J]. Journal of Catalysis 328: 151-164.

[5] Buyukkaya E.. 2010. Effects of biodiesel on a DI diesel engine performance, emission and combustion characteristics [J]. Fuel 89: 3099-2105.

[6] Pérez V.R. \& Bueno-López A.. 2015. Catalytic regeneration of Diesel Particulate Filters: Comparison of Pt and CePr active phases[J]. Chemical Engineering Journal 279: 79-85.

[7] Tzamkiozis T. et al. 2010. Diesel passenger car PM emissions: from Euro 1 to Euro 4 with particle filter[J]. Atmospheric Environment 44: 909-916.

[8] Tsang K.S. et al. 2010. Reducing emissions of a diesel engine using fumigation ethanol and a diesel oxidation catalyst[J]. Energy and Fuels 24: 6156-6165.

[9] Winkler A. et al. 2009. The influence of chemical and thermal aging on the catalytic activity of a monolithic diesel oxidation catalyst[J]. Applied Catalysis B: Environmental 93: 177-184.

[10] Maik B. et al. 2009. On-road and laboratory investigation of low-level PM emissions of a modern diesel particulate filter equipped diesel passenger car[J]. Atmospheric Environment 43:19081916.

[11] Kim J. et al. 2012. Comparison studies on sintering phenomenon of diesel oxidation catalyst depending upon aging conditions[J]. Catalysis Today 185(1): 296-301.

[12] Zhou Q.H. et al. 2015. Nanostructured platinum catalyst coating on diesel particulate filter with a low-cost electroless deposition approach[J]. Chemical Engineering Journal 270:320-326.

[13] Millo F. et al. 2015. Impact on vehicle fuel economy of the soot loading on diesel particulate filters made of different substrate materials[J]. Energy 86:19-30.

[14] He C.et al. 2015. High $\mathrm{NO}_{2} / \mathrm{NOx}$ emissions downstream of the catalytic diesel particulate filter: An influencing factor study[J]. Journal of Environmental Sciences 35(1): 55-61.

[15] Ramdas R. et al. 2015. Using real particulate matter to evaluate combustion catalysts for direct regeneration of diesel soot filters[J]. Applied Catalysis B: Environmental 176: 436-443.

[16] Young L.H. et al. 2012. Effects of biodiesel, engine load and diesel particulate filter on nonvolatile particle number size distributions in heavy-duty diesel engine exhaust[J]. Journal of Hazardous Materials 199: 282-289. 